Keywords:

DWPF

Canister

Thermal Model

Retention: permanent

\title{
COMSOL Multiphysics Model for DWPF Canister Filling, Revision 1
}

M.R.Kesterson

September 8, 2011

Applied Computational Engineering and Statistics Savannah River National Laboratory

Aiken, SC 29808

This document was prepared in conjunction with work accomplished under Contract No. DE-AC09-08SR22470 with the U.S. Department of Energy.

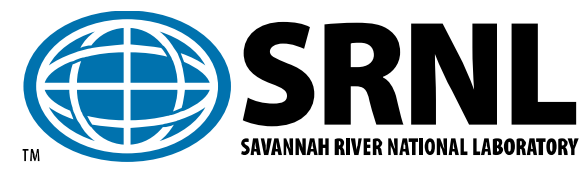




\section{DISCLAIMER}

This work was prepared under an agreement with and funded by the U.S. Government. Neither the U.S. Government or its employees, nor any of its contractors, subcontractors or their employees, makes any express or implied: 1 . warranty or assumes any legal liability for the accuracy, completeness, or for the use or results of such use of any information, product, or process disclosed; or 2. representation that such use or results of such use would not infringe privately owned rights; or 3. endorsement or recommendation of any specifically identified commercial product, process, or service. Any views and opinions of authors expressed in this work do not necessarily state or reflect those of the United States Government, or its contractors, or subcontractors.

This document was prepared in conjunction with work accomplished under Contract No. DE-AC09-08SR22470 with the U.S. Department of Energy. 


\section{AUTHORS:}

M.R, Kesterson, Applied Computational Engineering and Statistics

Date Savannah River National Laboratory

\section{TECHNICAL REVIEWERS:}

N.K.Gupta, Applied Computational Engineering and Statistics

Date Savannah River National Laboratory

\section{APPROVERS:}

J.W. Amoroso, Customer

Date

Process Technology Programs

P.L. Lee, Manager Applied Computational Engineering and Statistics Date Savannah River National Laboratory 


\begin{tabular}{|l|l|l|l|}
\hline $\begin{array}{l}\text { Revision } \\
\text { Number: }\end{array}$ & $\begin{array}{l}\text { Page } \\
\text { Number: }\end{array}$ & Date: & Revision: \\
\hline 0 & All & $3 / 31 / 2011$ & Original issue \\
\hline 1 & All & $9 / 8 / 2011$ & $\begin{array}{l}\text { Updated model parameters and } \\
\text { resultant simulations based on revised } \\
\text { method of incorporating the heat loss in } \\
\text { the computer model. }\end{array}$ \\
\hline
\end{tabular}




\section{Table of Contents}

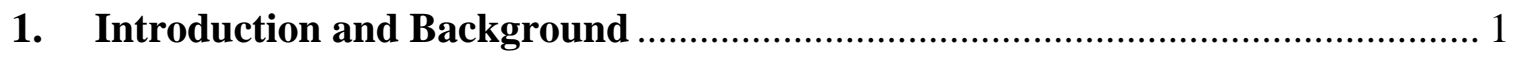

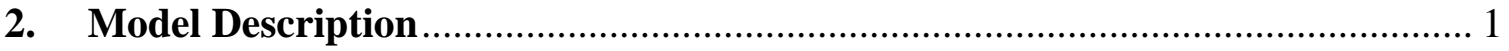

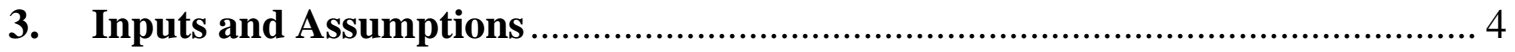

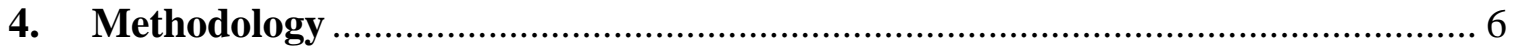

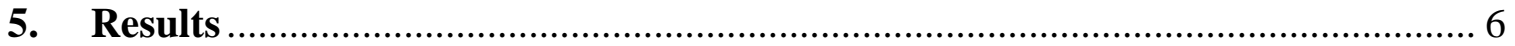

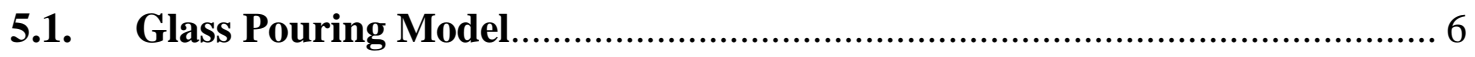

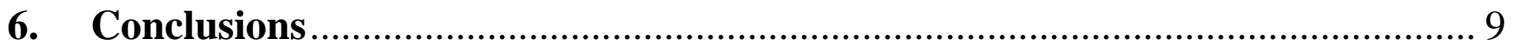

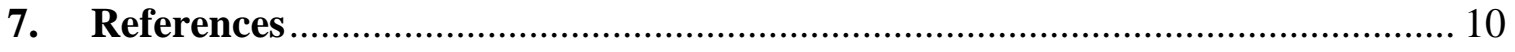

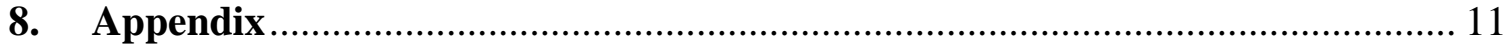

Appendix A - Comsol Constants and Expressions.............................................. 11

Appendix B - Simulation Temperature versus Time Data.................................... 15

\section{List of Tables}

Table 1 - Material Properties of Canister............................................................................. 5

Table 2 - Material Properties of DWPF glass ................................................................. 5

\section{List of Figures}

Figure 1 - COMSOL Multiphysics model of the DWPF canister. .................................. 2

Figure 4 - Temperature curves for thermocouple and simulation data located on the

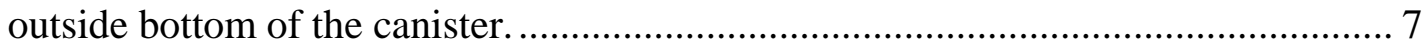

Figure 5 - Temperature curves for thermocouple and simulation data at the 15 inch location of the canister. ........................................................................................ 7

Figure 6 - Temperature curves for thermocouple and simulation data at the 51 inch

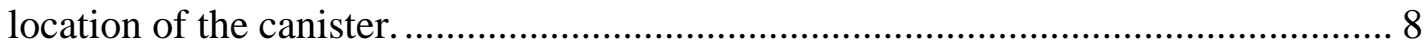

Figure 7 - Temperature curves for thermocouple and simulation data at the 87 inch location of the canister. ............................................................................... 8

Figure 8 - Temperature curves for thermocouple and simulation data at the 99 inch location of the canister. 


\section{Introduction and Background}

This revision is an extension of the COMSOL Multiphysics model previously developed and documented to simulate the temperatures of the glass during pouring a Defense Waste Processing Facility (DWPF) canister. In that report the COMSOL Multiphysics model used a lumped heat loss term derived from experimental thermocouple data based on a nominal pour rate of $228 \mathrm{lbs} . / \mathrm{hr}$. As such, the model developed using the lumped heat loss term had limited application without additional experimental data.

Therefore, the COMSOL Multiphysics model was modified to simulate glass pouring and subsequent heat input which, replaced the heat loss term in the initial model. This new model allowed for changes in flow geometry based on pour rate as well as the ability to increase and decrease flow and stop and restart flow to simulate varying process conditions.

This work was funded by the Department of Energy (DOE) Office of Environmental Management (EM) technology development task EM-31 WP-5.1.2.

\section{Model Description}

A simplified model for the DWPF canister and interior space consisting of 13,712 elements was created in Comsol Multiphysics and is shown in Figure 1. The geometry of the model was not modified in this revision. The difference between this model and the previous one is the inclusion of a glass stream along the centerline of the container during the pour phase. This section of glass is given a convective heat transfer term based on the velocity of the glass, basically yielding a forced convection term. Radiative heat transfer from the pouring glass stream to the container walls was not used. The model was created with the ability to vary the radius of the glass stream based on the pour rate and height. As a result, there was no fixed glass boundary to use for radiative heat transfer. As before, the model also incorporated heat transfer by conduction and convection in the gas phase.

For initial stabilization of the simulations, the model contained a small region pre-filled with glass with a volume equivalent to the first 10 minutes of pouring. The region is initialized to the thermal properties of the glass with an initial temperature of $100^{\circ} \mathrm{C}$. This region added a buffer to the sudden transition from air to glass and the resultant change in thermal mass within the canister. 


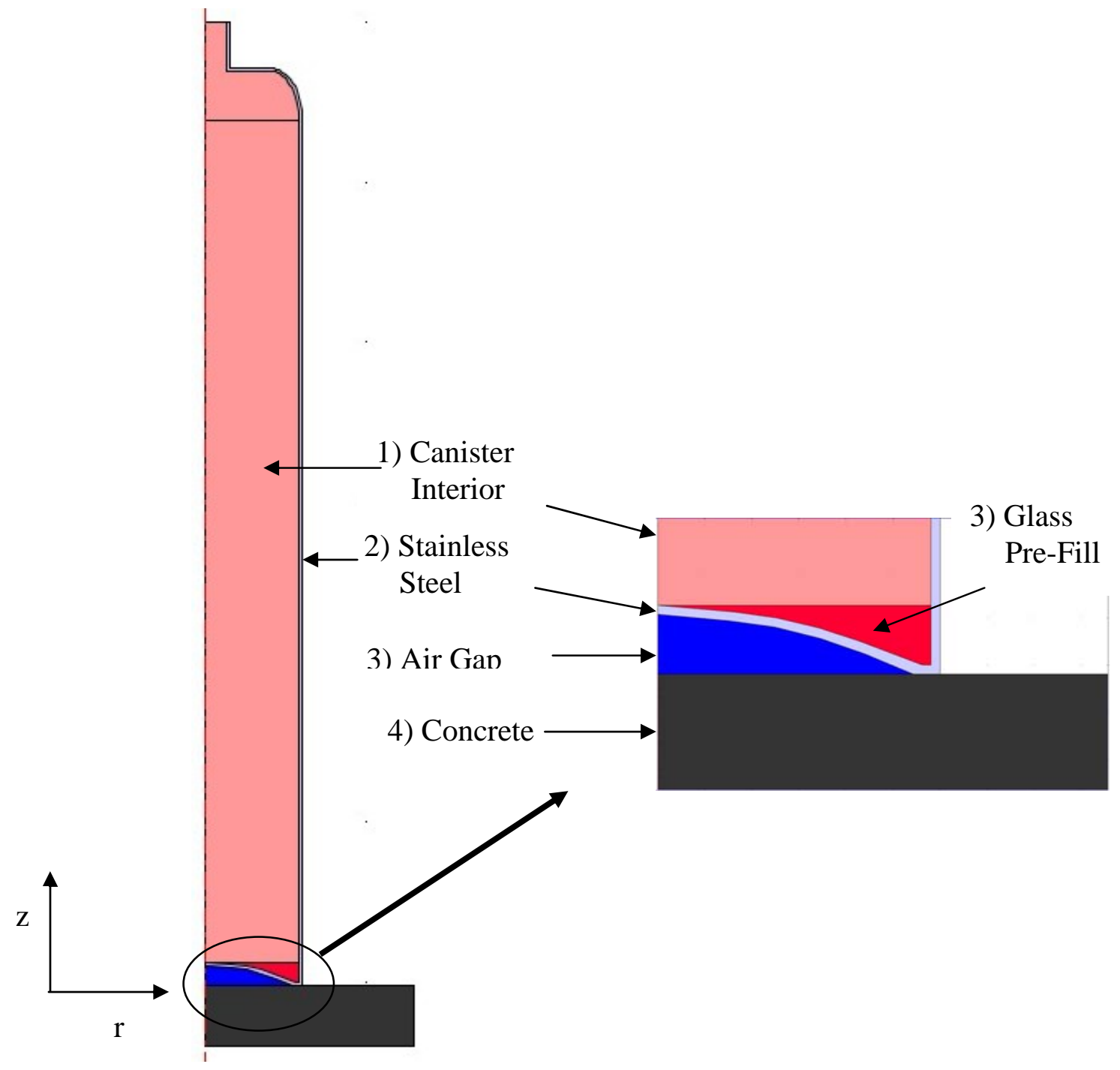

Figure 1 - COMSOL Multiphysics model of the DWPF canister.

The model incorporated convective heat transfer on the outer surface of the canister as the glass via radiative heat transfer from the surface of the glass.

A two-step method was used to model convective heat transfer in the glass phase. The first step was to model the glass stream along the centerline of the container and above the current fluid height. A variable named glass_r was used to calculate the radius of the glass stream as a function of pour rate and vertical position within the container. It was assumed that the glass was poured from a spout approximately $1 \mathrm{ft}$ above the entrance of the canister, giving an initial velocity of the glass.

For a system with an initial velocity of 0 , the z-displacement is equal to:

$$
D=\frac{a}{2} \cdot t^{2}
$$


Knowing $\mathrm{a}=9.8 \mathrm{~m} / \mathrm{s}^{2}$, and $\mathrm{D}=1 \mathrm{ft}$, the time to reach the entrance to the canister was calculated. Next, the velocity of the glass when it reaches the canister opening was calculated by:

$$
v=a \cdot t
$$

With the calculated velocity, and knowing the volumetric flowrate of the glass, the crosssectional area of the glass can be obtained, and therefore the entrance glass_ $r$ value.

$$
\begin{aligned}
& A=\frac{V}{v} \\
& t=\sqrt{\frac{2 \cdot(3.3048-z)}{a}} \\
& v=\sqrt{2 \cdot a \cdot(3.3048-z)} \\
& \text { glass_r } r_{\text {entrance }}=\sqrt{\frac{A}{\pi}}
\end{aligned}
$$

Where $\mathrm{z}=$ height(m), and the 3.3048 term is the combination of the canister height plus 1 foot above for the assumed pour height.

Applying a velocity increase due to gravity, the radius of the glass column was obtained as a function of the vertical height.

$$
\text { glass }_{-} r=\sqrt{\frac{V}{\pi \cdot \sqrt{2 \cdot a \cdot(3.3048-z)}}}
$$

where $\mathrm{V}=$ volumetric flowrate $\left(\mathrm{m}^{3} / \mathrm{s}\right)$; $\mathrm{a}=$ acceleration $\left(\mathrm{m} / \mathrm{s}^{2}\right)$, and $\mathrm{z}=$ height $(\mathrm{m})$.

Once the falling glass reached the current fill height, the convective heat transfer term was changed from a vertical flow to a radial flow. The maximum $\mathrm{z}$ velocity (calculated at the bottom of the canister) was used as the base value, multiplied by a power function, decreasing the velocity of the glass as it flows radially outward. The general form of the equation is: 


$$
v_{\text {glass_radial }}=C \cdot\left(\frac{R_{\text {inner_Wall }}-r}{R_{\text {inner_Wall }}}\right)^{(5+5 \cdot(z<0.25))}
$$

where

$\mathrm{v}_{\text {glass_radial }}=$ velocity of the glass flowing in the radial direction $(\mathrm{m} / \mathrm{s})$

$\mathrm{R}_{\text {inner_Wall }}=$ Inside radius of the canister $(\mathrm{m})$

$\mathrm{C}=$ Base radial velocity $0.08(\mathrm{~m} / \mathrm{s})$

$\mathrm{r}=$ radius at which the equation is evaluated $(\mathrm{m})$

$\mathrm{z}=$ Height at which the equation is evaluated (m)

The value for $\mathrm{C}$ along with the exponential factor were determined through simulation trial and error fits to the radial and vertical temperature profile seen in the experimental data.

\section{Inputs and Assumptions}

Below are the inputs and assumptions that are used in the COMSOL model. All units reported below are used in the model. The COMSOL model has a base unit system of SI, but the user is allowed to input properties in any units and COMSOL converts them to the base unit system for calculations.

Assumptions:

3.1. The ambient temperature in the room is a constant $26^{\circ} \mathrm{C}$. The experimental data shows that the room temperature had variations between $24^{\circ} \mathrm{C}$ and $30^{\circ} \mathrm{C}$ [0] with an average room temperature that was approximately $26^{\circ} \mathrm{C}$.

3.2. Radiation and convective heat transfer in the enclosed air space between the canister bottom and the ground is accounted for by an increased thermal conductivity term.

3.3. The experimental data used was based on scale glass melter run with a nominal pour rate of $228 \mathrm{lb} / \mathrm{hr}$ [0]. In reviewing the experimental data, the actual flow rate varied between 190 and $360 \mathrm{lb} / \mathrm{hr}$. A step function was employed in the model to approximate the flow rate variation and more accurately match the experimental conditions. The function is shown in Appendix A - Global Expressions table 
Inputs:

3.4. Glass pour temperature is $1080^{\circ} \mathrm{C}$

3.5. Canister dimensions are supplied on drawing W747391 [0]

3.6. Material Properties - Table 1 and Table 2

Table 1 - Material Properties of Canister

\begin{tabular}{|c|c|c|c|c|c|}
\hline Material & \multicolumn{2}{|c|}{ Thermal Conductivity } & Density & \multicolumn{2}{|c|}{ Specific Heat } \\
\hline \multirow{8}{*}{$\begin{array}{l}\text { Stainless } \\
\text { Steel } \\
\text { Canister } \\
{[0]}\end{array}$} & $\frac{B T U}{h r \cdot f t \cdot{ }^{o} F}$ & Temperature $\left({ }^{\circ} \mathrm{F}\right)$ & \multirow[t]{8}{*}{494.429} & \multirow[t]{2}{*}{$\frac{B T U}{l b_{m} \cdot{ }^{o} F}$} & \multirow[t]{2}{*}{$\begin{array}{c}\text { Temperature } \\
\left({ }^{\circ} \mathrm{F}\right)\end{array}$} \\
\hline & 3.9915 & -328 & & & \\
\hline & 6.28963 & -148 & & \multirow[t]{2}{*}{0.120} & \multirow[t]{2}{*}{32} \\
\hline & 7.74108 & 32 & & & \\
\hline & 9.43444 & 212 & & \multirow[t]{2}{*}{0.135} & \multirow[t]{2}{*}{752} \\
\hline & 12.5793 & 932 & & & \\
\hline & 14.9983 & 1292 & & \multirow[t]{2}{*}{0.135} & \multirow[t]{2}{*}{3000} \\
\hline & 14.9983 & 3000 & & & \\
\hline
\end{tabular}

Table 2 - Material Properties of DWPF glass

\begin{tabular}{|c|c|c|c|c|c|c|}
\hline \multirow{2}{*}{$\begin{array}{l}\text { Material } \\
\text { Glass } \\
{[0]}\end{array}$} & \multicolumn{2}{|c|}{ Thermal Conductivity } & \multicolumn{2}{|c|}{ Density } & \multicolumn{2}{|c|}{ Specific Heat } \\
\hline & \multirow[t]{2}{*}{$\frac{B T U}{h r \cdot f t \cdot{ }^{o} F}$} & \multirow[t]{2}{*}{$\begin{array}{c}\text { Temperature } \\
\left({ }^{\circ} \mathrm{F}\right)\end{array}$} & \multirow[t]{2}{*}{$\left(\mathrm{lb}_{\mathrm{m}} / \mathrm{ft}^{3}\right)$} & \multirow[t]{2}{*}{$\begin{array}{l}\text { Temperature } \\
\qquad\left({ }^{\circ} \mathrm{F}\right)\end{array}$} & $\frac{B T U}{l b_{m} \cdot{ }^{\circ} \mathrm{F}}$ & $\begin{array}{c}\text { Temperature } \\
\left({ }^{\circ} \mathrm{F}\right)\end{array}$ \\
\hline & & & & & 0.204 & 20 \\
\hline & \multirow[b]{2}{*}{0.76449} & \multirow[b]{2}{*}{20} & \multirow[t]{2}{*}{172.31} & \multirow[t]{2}{*}{20} & 0.204 & 68 \\
\hline & & & & & 0.24 & 212 \\
\hline & \multirow[b]{2}{*}{0.76449} & \multirow[b]{2}{*}{68} & \multirow[t]{2}{*}{171.37} & \multirow[t]{2}{*}{392} & 0.272 & 392 \\
\hline & & & & & 0.295 & 572 \\
\hline & \multirow[b]{2}{*}{0.76449} & \multirow[b]{2}{*}{1742} & \multirow{2}{*}{167.31} & \multirow[t]{2}{*}{932} & 0.312 & 752 \\
\hline & & & & & 0.325 & 932 \\
\hline & \multirow[b]{2}{*}{1.3741} & \multirow[b]{2}{*}{1832} & \multirow{2}{*}{165.44} & \multirow[t]{2}{*}{112} & 0.334 & 1112 \\
\hline & & & & & 0.342 & 1292 \\
\hline & \multirow[b]{2}{*}{2.8063} & \multirow[b]{2}{*}{2012} & \multirow[t]{2}{*}{162.94} & \multirow[t]{2}{*}{1292} & 0.349 & 1472 \\
\hline & & & & & 0.354 & 1652 \\
\hline & \multirow[b]{2}{*}{3.5079} & \multirow[b]{2}{*}{2102} & \multirow[t]{2}{*}{160.45} & \multirow[t]{2}{*}{1472} & 0.356 & 1740 \\
\hline & & & & & 0.358 & 1832 \\
\hline & \multirow{4}{*}{3.5079} & \multirow{4}{*}{3000} & \multirow[t]{2}{*}{157.95} & \multirow[t]{2}{*}{1652} & 0.362 & 2012 \\
\hline & & & & & 0.363 & 2102 \\
\hline & & & 151.77 & 2192 & 0.365 & 2192 \\
\hline & & & & & 0.365 & 3000 \\
\hline
\end{tabular}

The model consisted of two additional regions requiring material properties. These regions were the floor below the canister and the air initially contained within the canister and the air trapped between the canister and the concrete floor. The floor was modeled as 
a concrete slab with a lower temperature boundary condition equal to the ambient air temperature. The material library contained within COMSOL is used to obtain the material properties for both the air and concrete.

\section{Methodology}

Based on the time of the simulation and the time step, a corresponding volume of glass was added to the system by changing the material properties of the subdomain in the region between the calculated new glass height and the previous glass height (glass_height(t) - glass_height(dt)). The material properties for this region were changed from air to those of the glass, specifically changing the specific heat, density, and thermal conductivity. At the same time, the radial heat flow term, (Eq 8), adds heat to the new glass region.

Multiple simulations were run in order to obtain the constants in the radial glass velocity equations. The constants were obtained by using an initial guess, running the simulation and comparing the simulated results to the experimental data. Based on the outcome of the comparison, the constants were modified and the simulations re-run. This process was repeated multiple times until the simulation results approximated the experimental data.

\section{Results}

\subsection{Glass Pouring Model}

Figures Figure 2 toFigure 6 show the final results obtained from the model at five thermocouple locations: 1) bottom surface of the canister, 2) 15 inches, 3) 51 inches, 4) 87 inches, and 5) 99 inches. The larger temperature differences predicted at the 99 inch height are due to the lack of internal radiation from the top surface of the glass to the interior canister walls.

As seen in the following figures, the temperatures of the glass and the canister surface predicted using the model compare relatively well with the experimental data for both filling and cooling. For the end time of 3000 minutes, the simulations predict a temperature of approximately $30^{\circ} \mathrm{C}$ higher, at the 87 inch thermocouple, than the experimental data. 
Temperature (Bottom)

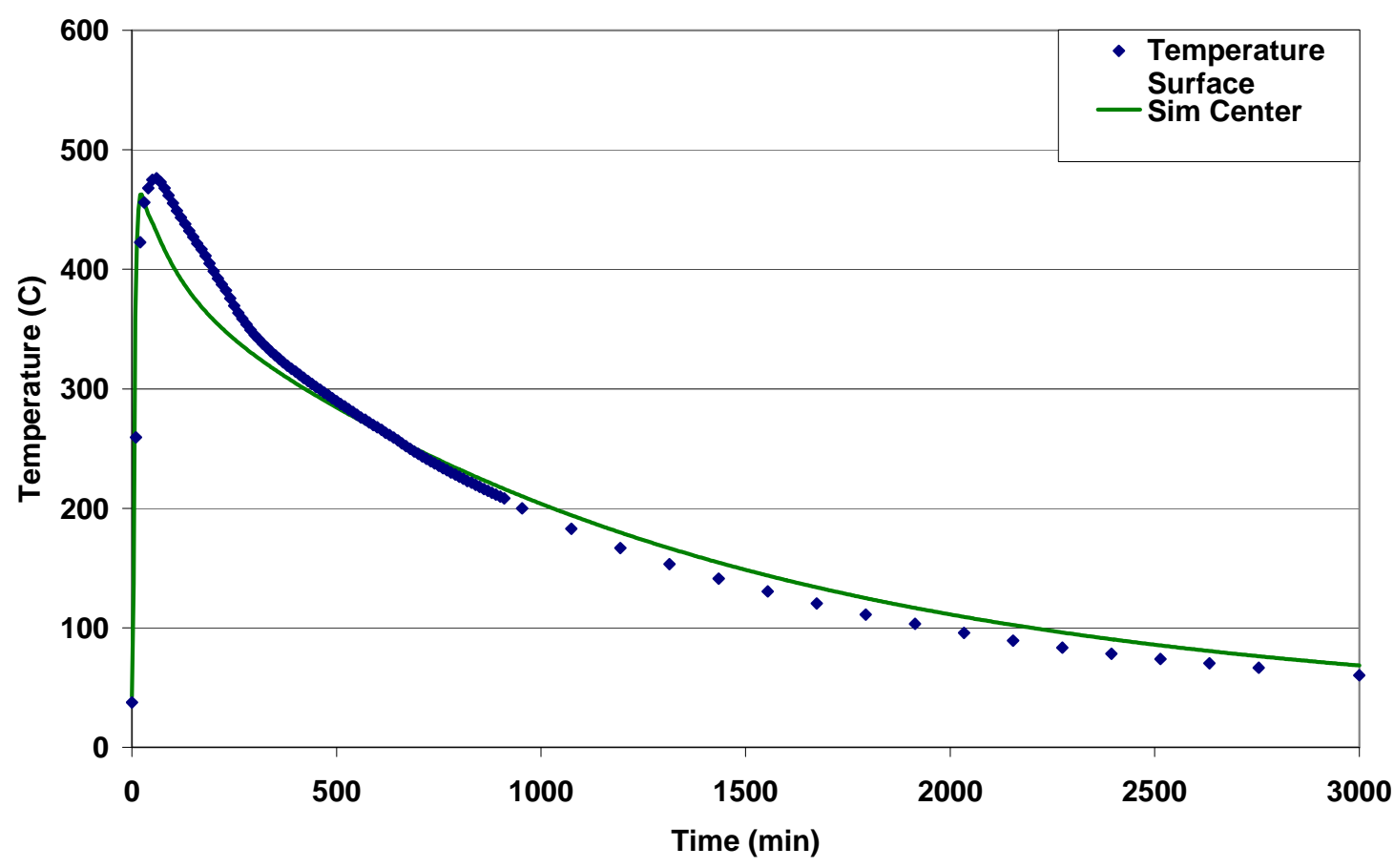

Figure 2 - Temperature curves for thermocouple and simulation data located on the outside bottom of the canister.

\section{Temperature (15 Inch)}

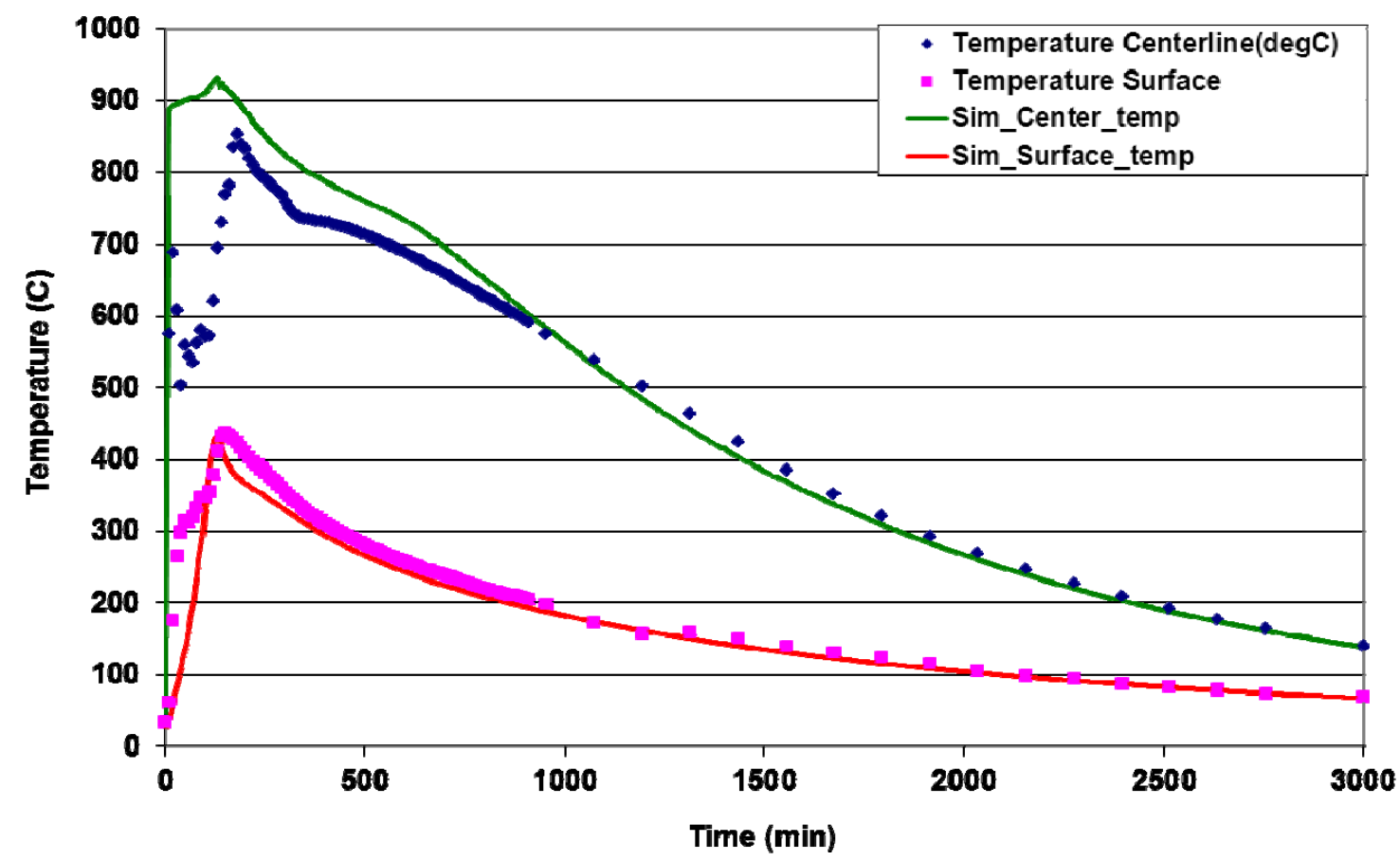

Figure 3 - Temperature curves for thermocouple and simulation data at the 15 inch location of the canister. 
Temperature (51 inch)

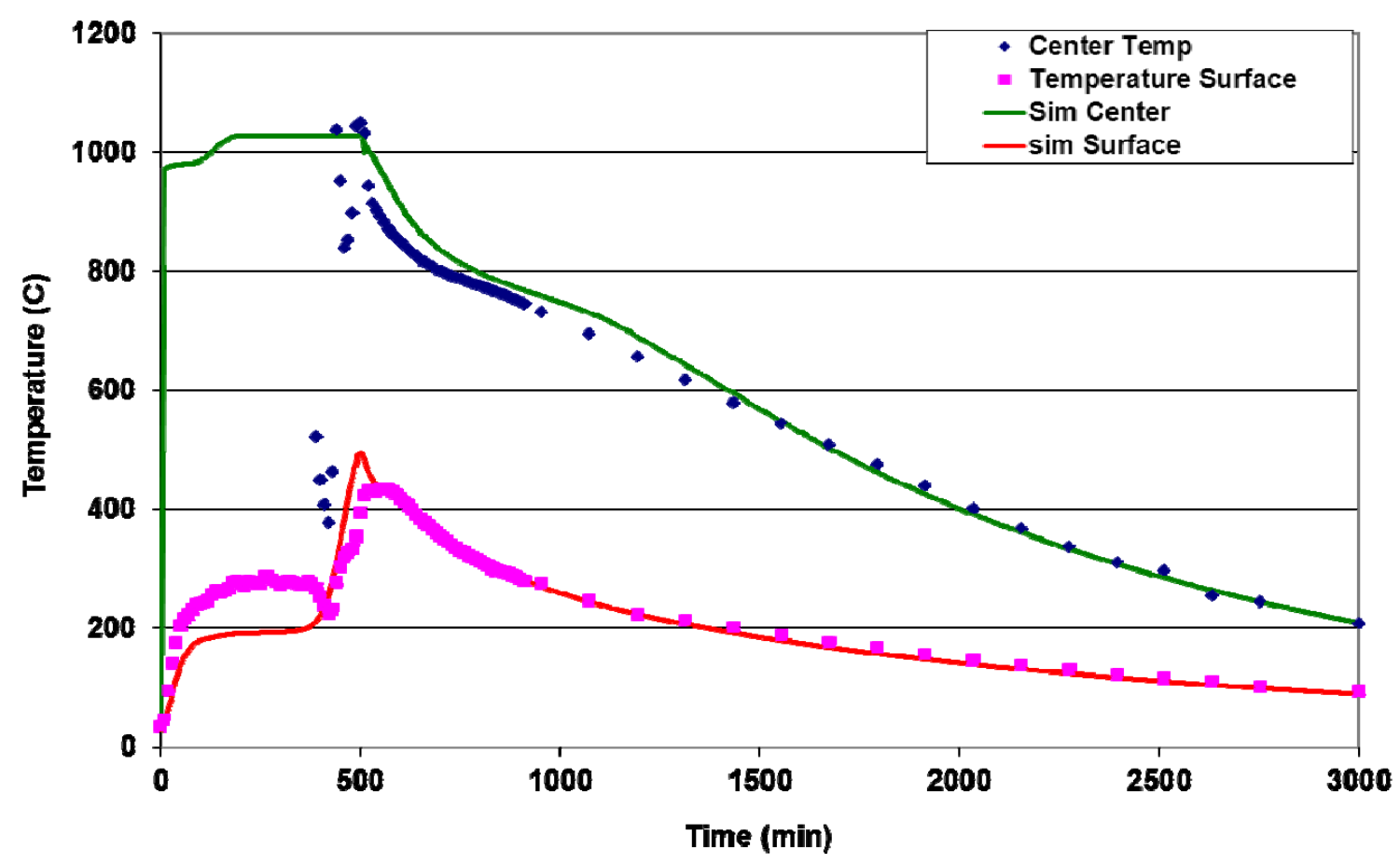

Figure 4 - Temperature curves for thermocouple and simulation data at the 51 inch location of the canister.

Temperature (87 inch)

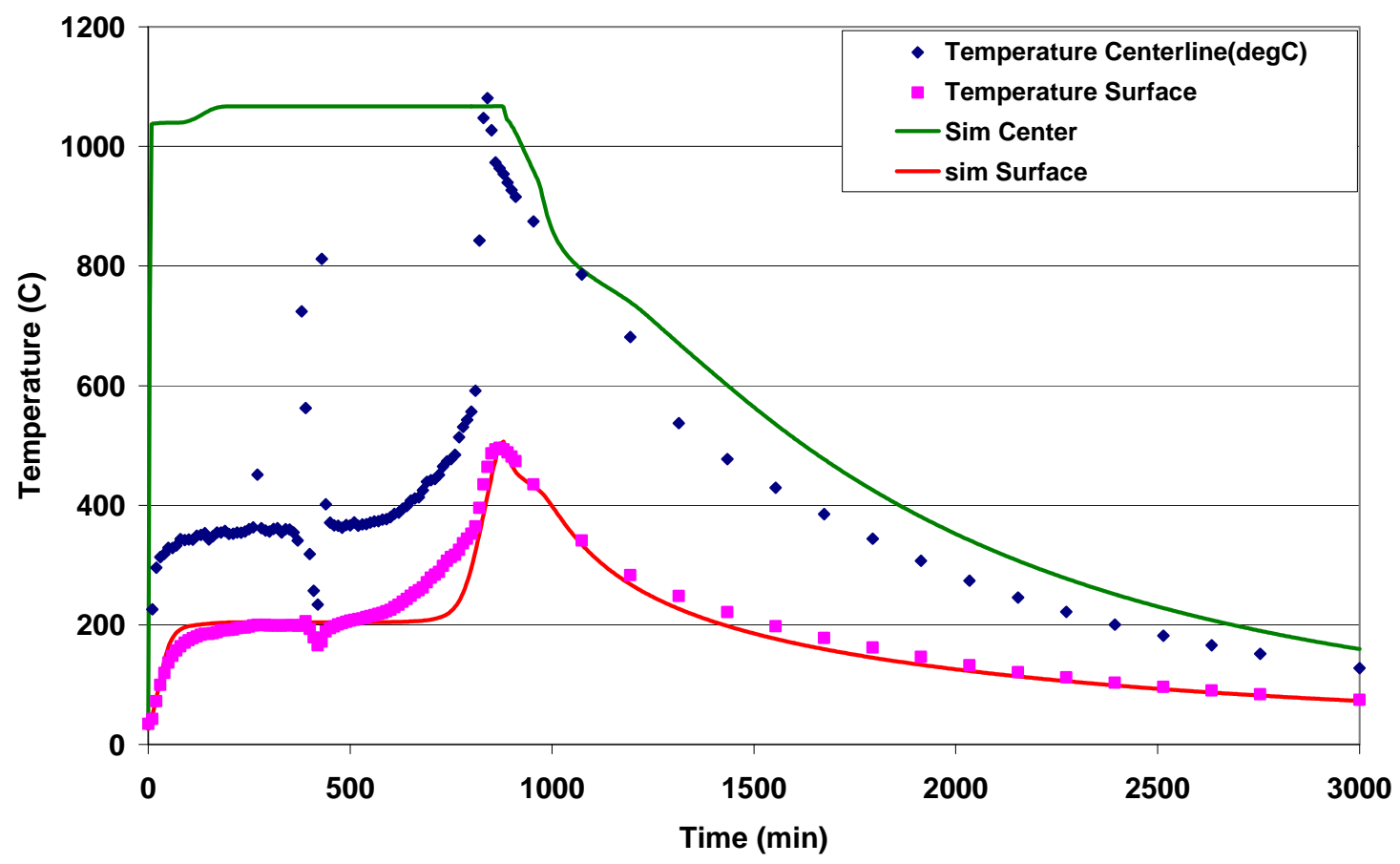

Figure 5 - Temperature curves for thermocouple and simulation data at the 87 inch location of the canister. 


\section{Temperature (99 inch)}

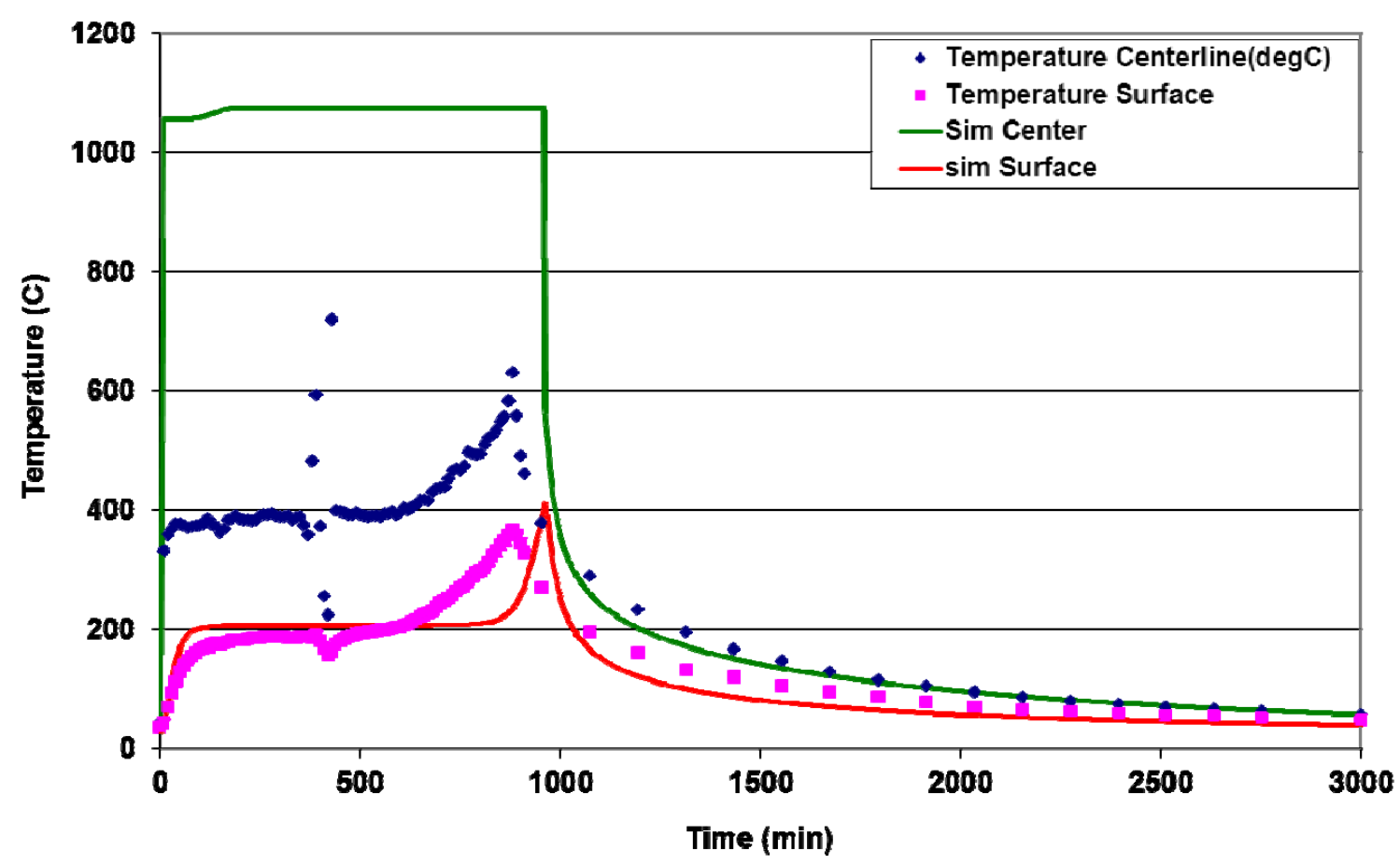

Figure 6 - Temperature curves for thermocouple and simulation data at the 99 inch location of the canister.

As seen in the thermocouple plots, there is a large difference in the simulated temperature and the experimental temperature for all of the centerline thermocouples prior to the fill level reaching the thermocouple height. This is due to the simulation pouring glass down the exact centerline of the canister thereby covering the simulation thermocouple location with hot glass.

\section{Conclusions}

A revised COMSOL Multiphysics model was developed to predict temperatures of the glass within DWPF canisters during filling and cooldown. The model simulations and experimental data were in good agreement. The largest temperature deviations were $\sim 40^{\circ} \mathrm{C}$ for the 87inch thermocouple location at 3000 minutes and during the initial cool down at the 51 inch location occurring at approximately 600 minutes. Additionally, the model described in this report predicts the general temperature trends during filling and cooling as observed experimentally.

The revised model incorporates a heat flow region corresponding to the glass pouring down the centerline of the canister. The geometry of this region is dependent on the flow rate of the glass and can therefore be used to see temperature variations for various pour rates. The equations used for this model were developed by comparing simulation output to experimental data from a single pour rate. Use of the model will predict temperature profiles for other pour rates but the accuracy of the simulations is unknown due to only a single flow rate comparison. 


\section{References}

1. COMSOL Multiphysics, Version 3.5a, COMSOL Inc, Burlington, MA.

2. J.R. Fowler, R.E. Edwards, S.L. Marra, and M.J. Plodinec, “Chemical Composition Projections for then DWPF Product”, WSRC-IM-91-116-1, Rev. 1, 1995.

3. Drawing - W747391, "Savannah River Plant Bldg 221S 200 Area DWPF - CDC Canister Assembly Mechanical”, 1984.

4. D.A. Tamburello, "Predicting Temperatures for AFCI Canistered Waste Glasses”, Interoffice Memorandum, SRNL-L5200-2009-00013, 2009. 


\section{Appendix}

\section{Appendix A - Comsol Constants and Expressions}

The following tables are the constants and global expressions directly exported from COMSOL.

\section{COMSOL Constants}

\begin{tabular}{|l|l|l|}
\hline Constant Name & Constant Value & Description \\
\hline gravity & $9.8\left[\mathrm{~m} / \mathrm{s}^{\wedge} 2\right]$ & Acceleration due to gravity \\
\hline glass_rho & $167\left[\mathrm{lb} / \mathrm{ft}^{\wedge} 3\right]$ & Glass Density as a constant \\
\hline inlet_area & $0.031416\left[\mathrm{~m}^{\wedge} 2\right]$ & Opening at the top of the canister \\
\hline Lower_area & $0.26512\left[\mathrm{~m}^{\wedge} 2\right]$ & Cross-sectional area of the canister \\
\hline glass_T_init & $1080[\mathrm{deg}]$ & Inlet glass temperature \\
\hline sigma & $5.67 \mathrm{e}-8\left[\mathrm{~W} / \mathrm{m}^{\wedge} 2 / \mathrm{K}^{\wedge} 4\right]$ & \\
\hline T_atm & $26[\mathrm{degC}]$ & Ambient Temperature \\
\hline SS_rho & $494.429\left[\mathrm{lb} / \mathrm{ft}^{\wedge} 3\right]$ & Density of stainless steel \\
\hline ContainerHeight & $3[\mathrm{~m}]$ & Height of the canister \\
\hline dt & $40[\mathrm{~s}]$ & Simulation timestep \\
\hline MaxGlass & $3656[\mathrm{lb}]$ & Amount of glass added to the canister \\
\hline MaxHeight & MaxGlass/glass_rho/Lower_area & Maximum height of the glass \\
\hline T_Lump_init & $100[\mathrm{degC}]$ & $\begin{array}{l}\text { Initial temperature of the lower glass } \\
\text { region }\end{array}$ \\
\hline int_emmisivity & $0.55[1]$ & Internal emissivity \\
\hline P_atm & $1[\mathrm{~atm}]$ & Internal air pressure \\
\hline PourRate & 228 & Unitless pour rate \\
\hline PourRateUnit & PourRate $1[\mathrm{lb} / \mathrm{h}]$ & Pour rate with units \\
\hline AirMaxFlow & $.1[\mathrm{~m} / \mathrm{s}]$ & Maximum internal air velocity \\
\hline BaseFlow & $228[\mathrm{lb} / \mathrm{h}]$ & Flow rate of the experimental data \\
\hline
\end{tabular}

\section{COMSOL Global Expressions}

\begin{tabular}{|c|c|c|}
\hline Vaiable Name & Expression & Description \\
\hline Fluid_Height & (Fluid_Height_new+0.07)^Filling+MaxHeight*(1-Filling) & Current Glass Height \\
\hline T_amb & $25[\operatorname{degC}]$ & Ambient Temperature \\
\hline delHeight & (z<=Fluid_Height) ${ }^{\star}(z>$ LastFluidHeight)[1] & $\begin{array}{l}\text { Switch for } z \text { between the } \\
\text { current and last fluid height }\end{array}$ \\
\hline Ra_init & $\begin{array}{l}\text { gravity }{ }^{\star} \text { Beta }^{\star}(T- \\
\text { T_atm })^{\star} \text { ContainerHeight^3/(air_visc*air_k/air_rho^2/air } \\
\text { cpp) }\end{array}$ & \\
\hline $\mathrm{Ra}$ & Ra_init*(Ra_init $>0)$ & \\
\hline Beta & $1 / \mathrm{T}$ & \\
\hline $\mathrm{Pr}$ & air_cp*air_visc/air_k & \\
\hline h_surface_low & $\begin{array}{l}\text { (air_k/ContainerHeight)* }{ }^{\star}\left(0.68+\left(0.670^{\star} \mathrm{Ra}^{\wedge} .25\right) /(1.0+(0 .\right. \\
\left.\left.492 / \mathrm{Pr})^{\wedge}(9 / 16)\right)^{\wedge}(4 / 9)\right)\end{array}$ & \\
\hline
\end{tabular}




\begin{tabular}{|c|c|c|}
\hline Vaiable Name & Expression & Description \\
\hline h_surface_high & $\begin{array}{l}\left((\text { air_k/ContainerHeight })^{\star}\left(0.825+\left(0.387^{\star} \mathrm{Ra}^{\wedge}(1 / 6)\right) /(1.0+\right.\right. \\
\left.\left.\left.(0.492 / \mathrm{Pr})^{\wedge}(9 / 16)\right)^{\wedge}(8 / 27)\right)^{\wedge} 2\right)\end{array}$ & \\
\hline h_surface & (h_surface_low* $(\mathrm{Ra}<=1 \mathrm{e} 9)+\mathrm{h} \_$surface_high $\left.{ }^{\star}(\mathrm{Ra}>1 \mathrm{e} 9)\right)$ & $\begin{array}{l}\text { Heat transfer coefficient for the } \\
\text { outside surface of the canister }\end{array}$ \\
\hline T_min & $T^{\star}(T>T$ atm-5)+T_atm*(T<=T_atm-5) & \\
\hline Filling & $(($ Fluid_Height_new+.01[m])<=MaxHeight)[1] & Switch for flow on/off \\
\hline Q_rad_top & sigma*((glass_T_init)^4-(T)^4)*Filling & \\
\hline emmisivity & $.85[1]$ & $\begin{array}{l}\text { External emissivity of the } \\
\text { canister }\end{array}$ \\
\hline glassFlow1 & $128[\mathrm{lb} / \mathrm{h}]^{\star \star t *}(\mathrm{t}<=905[\mathrm{~min}])$ & $\begin{array}{l}\text { Flowrate of glass for the first } \\
\text { time period. }\end{array}$ \\
\hline glassFlow2 & $\left(228[\mathrm{lb} / \mathrm{h}]^{\star}(\mathrm{t}-905[\mathrm{~min}])+\mathrm{glw} 1\right)^{\star}(\mathrm{t}>905[\mathrm{~min}])$ & $\begin{array}{l}\text { Flowrate of glass for the } \\
\text { second time period. }\end{array}$ \\
\hline glassFlow3 & $\begin{array}{l}\left(228[\mathrm{lb} / \mathrm{h}]^{*}(\mathrm{t}-\right. \\
270[\mathrm{~min}])+\mathrm{glw} 1+\mathrm{glw} 2)^{*}(\mathrm{t}>270[\mathrm{~min}])^{\star}(\mathrm{t}<=350[\mathrm{~min}])\end{array}$ & $\begin{array}{l}\text { Flowrate of glass for the third } \\
\text { time period. }\end{array}$ \\
\hline glassFlow4 & $\begin{array}{l}\left(228[\mathrm{lb} / \mathrm{h}]^{\star}(\mathrm{t}-\right. \\
350[\mathrm{~min}])+\mathrm{glw} 1+\mathrm{glw} 2+\mathrm{glw} 3)^{\star}(\mathrm{t}>350[\mathrm{~min}])^{\star}(\mathrm{t}<=500[\mathrm{~min}])\end{array}$ & $\begin{array}{l}\text { Flowrate of glass for the fourth } \\
\text { time period. }\end{array}$ \\
\hline glassFlow5 & $\begin{array}{l}\left(228[\mathrm{lb} / \mathrm{h}]^{\star}(\mathrm{t}-\right. \\
500[\mathrm{~min}])+\mathrm{glw} 1+\mathrm{glw} 2+\mathrm{glw} 3+\mathrm{glw} 4)^{\star}(\mathrm{t}>500[\mathrm{~min}])^{\star}(\mathrm{t}<=61 \\
0[\mathrm{~min}])\end{array}$ & $\begin{array}{l}\text { Flowrate of glass for the fifth } \\
\text { time period. }\end{array}$ \\
\hline glassFlow6 & $\begin{array}{l}\left(228[\mathrm{lb} / \mathrm{h}]^{\star}(\mathrm{t}-\right. \\
610[\mathrm{~min}])+\mathrm{glw} 1+\mathrm{glw} 2+\mathrm{glw} 3+\mathrm{glw} 4+\mathrm{glw} 5)^{\star}(\mathrm{t}>610[\mathrm{~min}])^{\star}(\mathrm{t} \\
<=730[\mathrm{~min}])\end{array}$ & $\begin{array}{l}\text { Flowrate of glass for the sixth } \\
\text { time period. }\end{array}$ \\
\hline glassFlow7 & $\begin{array}{l}\left(228[\mathrm{lb} / \mathrm{h}]^{\star}(\mathrm{t}-\right. \\
730[\mathrm{~min}])+\mathrm{glw} 1+\mathrm{glw} 2+\mathrm{glw} 3+\mathrm{glw} 4+\mathrm{glw} 5+\mathrm{glw} 6)^{\star}(\mathrm{t}>730[ \\
\min ])\end{array}$ & $\begin{array}{l}\text { Flowrate of glass for the } \\
\text { seventh time period. }\end{array}$ \\
\hline glw1 & $128[\mathrm{lb} / \mathrm{h}]^{\star} 905[\mathrm{~min}]$ & $\begin{array}{l}\text { Mass of glass accumulated } \\
\text { during the first time period }\end{array}$ \\
\hline glw2 & $228[\mathrm{lb} / \mathrm{h}]^{\star} 90[\mathrm{~min}]$ & $\begin{array}{l}\text { Mass of glass accumulated } \\
\text { during the second time period }\end{array}$ \\
\hline glw3 & $228[\mathrm{lb} / \mathrm{h}]^{\star} 80[\mathrm{~min}]$ & $\begin{array}{l}\text { Mass of glass accumulated } \\
\text { during the third time period }\end{array}$ \\
\hline glw4 & $228[\mathrm{lb} / \mathrm{h}]^{\star} 150[\mathrm{~min}]$ & $\begin{array}{l}\text { Mass of glass accumulated } \\
\text { during the fourth time period }\end{array}$ \\
\hline glw5 & $228[\mathrm{lb} / \mathrm{h}]^{\star 1} 10[\mathrm{~min}]$ & $\begin{array}{l}\text { Mass of glass accumulated } \\
\text { during the fifth time period }\end{array}$ \\
\hline glw6 & $228[\mathrm{lb} / \mathrm{h}]^{\star} 120[\mathrm{~min}]$ & $\begin{array}{l}\text { Mass of glass accumulated } \\
\text { during the sixth time period }\end{array}$ \\
\hline $\begin{array}{l}\text { Fluid_Height_ne } \\
\text { W_const }\end{array}$ & PourRateUnit*t/glass_rho/Lower_area & $\begin{array}{l}\text { Fluid height calculated with a } \\
\text { constant pour rate }\end{array}$ \\
\hline $\begin{array}{l}\text { Fluid_Height_ne } \\
\text { w }\end{array}$ & (glassFlow1+glassFlow2)/glass_rho/Lower_area & $\begin{array}{l}\text { Fluid height calculated using } \\
\text { step changes in flow rate }\end{array}$ \\
\hline glassFlow1_dt & $128[\mathrm{lb} / \mathrm{h}]^{\star}(\mathrm{t}-\mathrm{dt})^{\star}(\mathrm{t}<=905[\mathrm{~min}])$ & $\begin{array}{l}\text { Mass of glass accumulated } \\
\text { during the first time period-the } \\
\text { timestep }\end{array}$ \\
\hline glassFlow2_dt & $\left(228[\mathrm{lb} / \mathrm{h}]^{\star}(\mathrm{t}-\mathrm{dt}-905[\mathrm{~min}])+\mathrm{glw} 1\right)^{\star}(\mathrm{t}>905[\mathrm{~min}])$ & $\begin{array}{l}\text { Mass of glass accumulated } \\
\text { during the second time period- } \\
\text { the timestep }\end{array}$ \\
\hline glassFlow3_dt & $\begin{array}{l}\left(228[\mathrm{lb} / \mathrm{h}]^{*}(\mathrm{t}-\mathrm{dt}-\right. \\
270[\mathrm{~min}])+\mathrm{glw} 1+\mathrm{glw} 2)^{*}(\mathrm{t}>270[\mathrm{~min}])^{\star}(\mathrm{t}<=350[\mathrm{~min}])\end{array}$ & $\begin{array}{l}\text { Mass of glass accumulated } \\
\text { during the third time period-the } \\
\text { timestep }\end{array}$ \\
\hline
\end{tabular}




\begin{tabular}{|c|c|c|}
\hline Vaiable Name & Expression & Description \\
\hline glassFlow4_dt & $\begin{array}{l}\left(228[\mathrm{lb} / \mathrm{h}]^{\star}(\mathrm{t}-\mathrm{dt}-\right. \\
350[\mathrm{~min}])+\mathrm{glw} 1+\mathrm{glw} 2+\mathrm{glw} 3)^{\star}(\mathrm{t}>350[\mathrm{~min}])^{\star}(\mathrm{t}<=500[\mathrm{~min}])\end{array}$ & $\begin{array}{l}\text { Mass of glass accumulated } \\
\text { during the fourth time period- } \\
\text { the timestep }\end{array}$ \\
\hline glassFlow5_dt & $\begin{array}{l}\left(228[\mathrm{lb} / \mathrm{h}]^{\star}(\mathrm{t}-\mathrm{dt}-\right. \\
500[\mathrm{~min}])+\mathrm{glw} 1+\mathrm{glw} 2+\mathrm{glw} 3+\mathrm{glw} 4)^{\star}(\mathrm{t}>500[\mathrm{~min}]) \star(\mathrm{t}<=61 \\
0[\mathrm{~min}])\end{array}$ & $\begin{array}{l}\text { Mass of glass accumulated } \\
\text { during the fifth time period-the } \\
\text { timestep }\end{array}$ \\
\hline glassFlow6_dt & $\begin{array}{l}\left(228[\mathrm{lb} / \mathrm{h}]^{\star}(\mathrm{t}-\mathrm{dt}-\right. \\
610[\mathrm{~min}])+\mathrm{glw} 1+\mathrm{glw} 2+\mathrm{glw} 3+\mathrm{glw} 4+\mathrm{glw} 5)^{\star}(\mathrm{t}>610[\mathrm{~min}])^{\star}(\mathrm{t} \\
<=730[\mathrm{~min}])\end{array}$ & $\begin{array}{l}\text { Mass of glass accumulated } \\
\text { during the sixth time period-the } \\
\text { timestep }\end{array}$ \\
\hline glassFlow7_dt & $\begin{array}{l}\left(228[\mathrm{lb} / \mathrm{h}]^{\star}(\mathrm{t}-\mathrm{dt}-\right. \\
730[\mathrm{~min}])+\mathrm{glw} 1+\mathrm{glw} 2+\mathrm{glw} 3+\mathrm{glw} 4+\mathrm{glw} 5+\mathrm{glw} 6)^{\star}(\mathrm{t}>730[ \\
\min ])\end{array}$ & $\begin{array}{l}\text { Mass of glass accumulated } \\
\text { during the seventh time } \\
\text { period-the timestep }\end{array}$ \\
\hline $\begin{array}{l}\text { LastFluidHeight } \\
\text { _const }\end{array}$ & PourRateUnit*(t-dt)/glass_rho/Lower_area+0.07[m] & $\begin{array}{l}\text { Fluid height from previous } \\
\text { timestep if constant pour rate } \\
\text { is used. }\end{array}$ \\
\hline LastFluidHeight & $\begin{array}{l}\text { ((glassFlow1_dt+glassFlow2_dt)/glass_rho/Lower_area } \\
\text { )+0.06[m] }\end{array}$ & $\begin{array}{l}\text { Fluid height from previous } \\
\text { timestep if variable pour rate is } \\
\text { used. }\end{array}$ \\
\hline z_vel_air & $\begin{array}{l}-0.7^{\star}\left(\mathrm{flc} \text { hs }\left(z[1 / \mathrm{m}]-(\text { Fluid_Height[1/m]+0.2),0.2) })^{\star}(0.15-\right.\right. \\
\mathrm{r}[1 / \mathrm{m}])^{\star} \text { z_vel_glass_base }{ }^{\star}(\mathrm{r}>\text { glass_rr })^{\star} \text { TimeFact }{ }^{\star} \text { Filling }\end{array}$ & \\
\hline r_vel_air & $\begin{array}{l}-0.7^{*}(z>\text { Fluid_Height })^{*} r \text { rvel_air_base }{ }^{*}(1-f \mathrm{fl} 2 \mathrm{hs}(\mathrm{z}[1 / \mathrm{m}]- \\
2.74,0.1))^{\star}(\mathrm{r}>\text { glass_r })^{*} \text { TimeFact*Filling }\end{array}$ & \\
\hline r_vel_air_base & AirMaxFlow $^{\star}\left(-44.444^{*}(\mathrm{r}[1 / \mathrm{m}])^{\wedge} 2+13.333333^{\star} \mathrm{r}[1 / \mathrm{m}]\right)$ & \\
\hline Entrance_Temp & $\begin{array}{l}\text { ((glass_T_init-T_atm) }{ }^{\star} \text { TimeFact+T_atm)*Filling }+T^{\star}(1- \\
\text { Filling) }\end{array}$ & $\begin{array}{l}\text { Inlet glass temperature with } \\
\text { ramping factor }\end{array}$ \\
\hline Z_vel_glass & $\begin{array}{l}\text { z_vel_glass_base*flc2hs(glass_r[1/m]- } \\
\text { r[1/m],0.0001)*flc2hs(z[1/m]- } \\
\text { (Fluid_Height[1/m]+delHeight),delHeight)*Filling }\end{array}$ & $\begin{array}{l}\text { Velocity of falling glass based } \\
\text { on height }\end{array}$ \\
\hline glass_r & $\begin{array}{l}\text { sqrt(PourRateUnit/glass_rho/pi/sqrt(2*gravity*(3.3048- } \\
\text { z)^Filling }\end{array}$ & Radius of the glass centerline \\
\hline TimeFact & flc2hs(t[1/s]-400,400)[1] & $\begin{array}{l}\text { Ramping factor for start of } \\
\text { simulation }\end{array}$ \\
\hline r_glass_vel & $\begin{array}{l}\left(-0.1^{\star}((0.295-r[1 / \mathrm{m}]) / 0.295)^{\wedge}\left(5+5^{\star} f l c 2 h s(0.25-\right.\right. \\
\text { Fluid_Height[1/m],0.1))+.00008)*delHeight* }(r>\text { glass_r })^{\star} \\
\text { Filling*FlowFactor }\end{array}$ & $\begin{array}{l}\text { Radial glass velocity at the } \\
\text { current glass height }\end{array}$ \\
\hline z_vel_glass_bas & $-\left(9.8^{\star}((3.3048-z[1 / \mathrm{m}]) / 4.9)^{\wedge}(0.5)\right)[\mathrm{m} / \mathrm{s}]$ & $\begin{array}{l}\text { Velocity of centerline glass } \\
\text { based on gravity }\end{array}$ \\
\hline FlowFactor & $\left(128[\mathrm{lb} / \mathrm{h}]+100[\mathrm{lb} / \mathrm{h}]^{\star} \mathrm{flc} 2 \mathrm{hs}(\mathrm{t}[1 / \mathrm{min}]-905,10)\right) /$ BaseFlow & \\
\hline SS_cp & $\begin{array}{l}\left(.12+.015^{\star} \mathrm{flc} 2 \mathrm{hs}(\mathrm{T}[1 / \mathrm{deg} F]-\right. \\
452[\mathrm{degF}][1 / \mathrm{deg}], 300))[\mathrm{Btu} / \mathrm{lb} / \mathrm{degF}]\end{array}$ & Heat capacity of stainless steel \\
\hline$\overline{\text { SS_k }}$ & $\left(-13.589083+3.9578316 * \log \left(T \_\min [1 / \mathrm{K}]\right)\right)[\mathrm{Btu} / \mathrm{h} / \mathrm{ft} / \mathrm{degF}]$ & $\begin{array}{l}\text { Thermal conductivity of } \\
\text { stainless steel }\end{array}$ \\
\hline glass_k & $\begin{array}{l}\left(1+0.2^{\star f \mid c} 2 \mathrm{hs}\left(\mathrm{T}[1 / \mathrm{degC}]_{-}\right.\right. \\
400,200)+8.5^{\star} \mathrm{flc} 2 \mathrm{hs}(\mathrm{T}[1 / \mathrm{degC}]- \\
800,100))[\mathrm{Btu} / \mathrm{h} / \mathrm{ft} / \mathrm{degF}]^{\star} 0.9\end{array}$ & $\begin{array}{l}\text { Temperature dependent } \\
\text { thermal conductivity for the } \\
\text { glass phase }\end{array}$ \\
\hline glass_rho_adap & $\begin{array}{l}\left(172.31^{\star}(T[\text { degC }]<20)+(T[\text { degC }]>=20)^{\star}(T[\text { degC }]<=1200\right. \\
)^{\star}\left(172.2011+.00109^{\star} T[1 / \text { degC }]-1.609 \mathrm{e}-\right. \\
5^{\star}(T[1 / \text { degC }])^{\wedge} 2-1.508162 \mathrm{e}-8^{\star}(T[1 / \text { degC }])^{\wedge} 3+1.3323 e- \\
\left.\left.11^{*}(T[1 / \text { degC }])^{\wedge} 4\right)+151.77^{\star}(T[\text { degC }]>1200)\right)\left[\left[\mathrm{lb} / \mathrm{ft}^{\wedge} 3\right]\right.\end{array}$ & $\begin{array}{l}\text { Temperature dependent } \\
\text { density for the glass phase }\end{array}$ \\
\hline glass_cp & $\left(0.45+0.2^{\star}\right.$ flc2hs(T[1/degC]-600,400))[Btu/lb/degF] & $\begin{array}{l}\text { Temperature dependent heat } \\
\text { capacity for the glass phase }\end{array}$ \\
\hline
\end{tabular}




\begin{tabular}{|c|c|c|}
\hline Vaiable Name & Expression & Description \\
\hline k_eff & 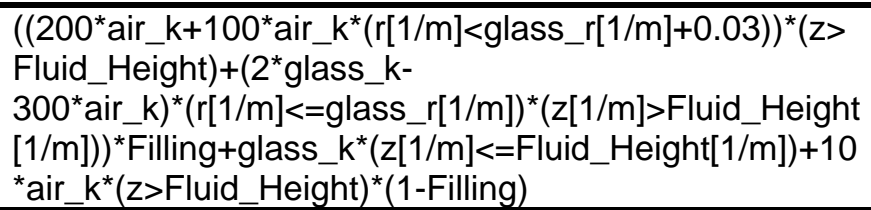 & $\begin{array}{l}\text { Thermal conductivity of the } \\
\text { region inside the canister. } \mathrm{k} \\
\text { changes from air to glass } \\
\text { based on fluid height. }\end{array}$ \\
\hline Cp_eff & $\begin{array}{l}\text { air_cp*(z>Fluid_Height)+glass_cp }{ }^{\star}(z<=\text { Fluid_Height })+( \\
\text { glass_cp-air_cp })^{\star}(r[1 / \mathrm{m}]<=\text { glass_r[1/m] })\end{array}$ & $\begin{array}{l}\text { Heat capacity of the region } \\
\text { inside the canister. Cp } \\
\text { changes from air to glass } \\
\text { based on fluid height. }\end{array}$ \\
\hline rho_eff & $\begin{array}{l}\text { air_rho*(z>Fluid_Height)+glass_rho_adap }{ }^{*}(z<=\text { Fluid_H } \\
\text { eight })+(\text { glass_rho_adap- } \\
\text { air_rho })^{\star}(r[1 / \mathrm{m}]<=\text { glass_r[1/m] })^{\star}(z>\text { Fluid_Height })\end{array}$ & $\begin{array}{l}\text { Density of the region inside the } \\
\text { canister. Density changes } \\
\text { from air to glass based on fluid } \\
\text { height. }\end{array}$ \\
\hline air_k & mat3_k(T[1/K])[W/(m*K)] & Air thermal conductivity \\
\hline air_rho & mat3_rho(P_atm[1/Pa],T[1/K])[kg/m^3] & Air density \\
\hline air_cp & mat3_Cp(T[1/K])[J/(kg*K)] & Air heat capacity \\
\hline
\end{tabular}




\section{Appendix B - Simulation Temperature versus Time Data}

\begin{tabular}{|c|c|c|c|c|c|c|c|c|c|}
\hline $\begin{array}{l}\text { Time } \\
(\mathrm{min})\end{array}$ & $\begin{array}{c}\text { Bottom } \\
\text { Surface } \\
\text { (C) }\end{array}$ & $\begin{array}{l}15 \text { Inch } \\
\text { Center } \\
\text { (C) }\end{array}$ & $\begin{array}{l}15 \text { Inch } \\
\text { Surface } \\
\text { (C) }\end{array}$ & $\begin{array}{l}51 \text { Inch } \\
\text { Center } \\
\text { (C) }\end{array}$ & $\begin{array}{l}51 \text { Inch } \\
\text { Surface } \\
\text { (C) }\end{array}$ & $\begin{array}{l}87 \text { Inch } \\
\text { Center } \\
\text { (C) }\end{array}$ & $\begin{array}{c}87 \text { Inch } \\
\text { Surface } \\
\text { (C) }\end{array}$ & $\begin{array}{l}99 \text { Inch } \\
\text { Center } \\
\text { (C) }\end{array}$ & $\begin{array}{l}99 \text { Inch } \\
\text { Surface } \\
\text { (C) }\end{array}$ \\
\hline 0 & 42.67 & 26.00 & 26.05 & 26.00 & 26.00 & 26.00 & 26.00 & 26.00 & 26.00 \\
\hline 20 & 462.34 & 892.71 & 62.61 & 976.63 & 70.39 & 1038.67 & 78.40 & 1057.26 & 80.28 \\
\hline 40 & 446.14 & 898.20 & 112.12 & 979.25 & 119.18 & 1039.27 & 140.66 & 1057.40 & 151.06 \\
\hline 60 & 431.19 & 901.92 & 168.45 & 980.70 & 154.07 & 1039.53 & 178.08 & 1057.45 & 185.48 \\
\hline 80 & 416.14 & 904.84 & 240.89 & 981.67 & 172.39 & 1039.86 & 192.54 & 1057.63 & 197.71 \\
\hline 100 & 402.88 & 912.15 & 340.44 & 986.27 & 180.03 & 1042.46 & 197.63 & 1059.39 & 201.95 \\
\hline 120 & 391.54 & 926.19 & 427.00 & 996.23 & 183.60 & 1048.26 & 199.83 & 1063.35 & 203.70 \\
\hline 140 & 381.58 & 923.82 & 414.92 & 1009.01 & 186.19 & 1055.73 & 201.33 & 1068.46 & 204.80 \\
\hline 160 & 372.71 & 912.01 & 388.76 & 1020.31 & 188.50 & 1062.33 & 202.60 & 1072.97 & 205.70 \\
\hline 180 & 364.71 & 899.52 & 375.29 & 1026.64 & 190.28 & 1066.03 & 203.53 & 1075.50 & 206.38 \\
\hline 200 & 357.44 & 884.83 & 366.71 & 1027.89 & 191.27 & 1066.75 & 204.01 & 1076.00 & 206.74 \\
\hline 220 & 350.73 & 870.12 & 359.38 & 1027.90 & 191.68 & 1066.76 & 204.17 & 1076.00 & 206.87 \\
\hline 240 & 344.51 & 856.43 & 352.04 & 1027.90 & 191.94 & 1066.76 & 204.22 & 1076.00 & 206.91 \\
\hline 260 & 338.68 & 844.24 & 344.48 & 1027.91 & 192.22 & 1066.76 & 204.24 & 1076.00 & 206.93 \\
\hline 280 & 333.18 & 833.44 & 336.82 & 1027.91 & 192.61 & 1066.76 & 204.24 & 1076.00 & 206.93 \\
\hline 300 & 327.96 & 823.81 & 329.19 & 1027.92 & 193.18 & 1066.76 & 204.24 & 1076.00 & 206.93 \\
\hline 320 & 322.98 & 815.14 & 321.70 & 1027.93 & 194.11 & 1066.76 & 204.25 & 1076.00 & 206.94 \\
\hline 340 & 318.19 & 807.27 & 314.44 & 1027.95 & 195.64 & 1066.76 & 204.25 & 1076.00 & 206.94 \\
\hline 360 & 313.57 & 800.05 & 307.43 & 1027.97 & 198.64 & 1066.76 & 204.25 & 1076.00 & 206.94 \\
\hline 380 & 309.10 & 793.37 & 300.70 & 1028.00 & 205.36 & 1066.76 & 204.25 & 1076.00 & 206.94 \\
\hline 400 & 304.75 & 787.13 & 294.25 & 1028.05 & 222.02 & 1066.76 & 204.25 & 1076.00 & 206.94 \\
\hline 420 & 300.51 & 781.25 & 288.09 & 1028.12 & 257.63 & 1066.76 & 204.26 & 1076.00 & 206.94 \\
\hline 440 & 296.38 & 775.66 & 282.19 & 1028.23 & 316.54 & 1066.76 & 204.26 & 1076.00 & 206.94 \\
\hline 460 & 292.32 & 770.29 & 276.55 & 1028.38 & 386.69 & 1066.76 & 204.27 & 1076.00 & 206.94 \\
\hline 480 & 288.35 & 765.08 & 271.17 & 1028.59 & 457.38 & 1066.76 & 204.28 & 1076.00 & 206.94 \\
\hline 500 & 284.45 & 759.95 & 266.01 & 1028.85 & 495.00 & 1066.76 & 204.30 & 1076.00 & 206.94 \\
\hline 520 & 280.62 & 754.85 & 261.07 & 1001.27 & 460.42 & 1066.76 & 204.33 & 1076.00 & 206.94 \\
\hline 540 & 276.85 & 749.69 & 256.33 & 981.82 & 440.53 & 1066.76 & 204.38 & 1076.00 & 206.95 \\
\hline 560 & 273.14 & 744.40 & 251.79 & 957.15 & 430.24 & 1066.76 & 204.45 & 1076.00 & 206.95 \\
\hline 580 & 269.49 & 738.87 & 247.42 & 932.30 & 420.46 & 1066.76 & 204.55 & 1076.00 & 206.96 \\
\hline 600 & 265.89 & 732.98 & 243.22 & 909.53 & 409.89 & 1066.76 & 204.72 & 1076.00 & 206.98 \\
\hline 620 & 262.34 & 726.59 & 239.17 & 889.80 & 398.84 & 1066.76 & 204.98 & 1076.00 & 207.00 \\
\hline 640 & 258.84 & 719.59 & 235.27 & 873.09 & 387.74 & 1066.76 & 205.39 & 1076.00 & 207.03 \\
\hline 660 & 255.40 & 711.95 & 231.51 & 858.93 & 376.94 & 1066.76 & 206.02 & 1076.00 & 207.09 \\
\hline 680 & 252.00 & 703.80 & 227.87 & 846.73 & 366.57 & 1066.76 & 207.06 & 1076.00 & 207.17 \\
\hline 700 & 248.65 & 695.31 & 224.35 & 836.06 & 356.68 & 1066.77 & 208.80 & 1076.00 & 207.29 \\
\hline 720 & 245.34 & 686.60 & 220.95 & 826.61 & 347.31 & 1066.77 & 211.95 & 1076.00 & 207.49 \\
\hline 740 & 242.09 & 677.77 & 217.65 & 818.16 & 338.45 & 1066.78 & 217.91 & 1076.00 & 207.81 \\
\hline 760 & 238.87 & 668.90 & 214.45 & 810.52 & 330.09 & 1066.80 & 230.13 & 1076.00 & 208.30 \\
\hline 780 & 235.71 & 660.08 & 211.34 & 803.55 & 322.20 & 1066.82 & 253.88 & 1076.00 & 209.07 \\
\hline 800 & 232.59 & 651.39 & 208.32 & 797.13 & 314.76 & 1066.85 & 295.01 & 1076.00 & 210.37 \\
\hline 820 & 229.51 & 642.67 & 205.38 & 791.18 & 307.73 & 1066.90 & 351.78 & 1076.00 & 212.53 \\
\hline 840 & 226.48 & 633.82 & 202.53 & 785.61 & 301.09 & 1066.98 & 415.66 & 1076.01 & 216.21 \\
\hline 860 & 223.49 & 624.89 & 199.74 & 780.36 & 294.80 & 1067.07 & 475.02 & 1076.02 & 222.84 \\
\hline 880 & 220.55 & 615.93 & 197.03 & 775.37 & 288.84 & 1065.94 & 506.51 & 1076.03 & 235.50 \\
\hline
\end{tabular}


COMSOL Multiphysics Model for DWPF Canister Filling SRNL-STI-2011-00209
Revision 1

September 8, 2011

\begin{tabular}{|c|c|c|c|c|c|c|c|c|c|}
\hline 900 & 217.65 & 606.96 & 194.39 & 770.58 & 283.18 & 1033.97 & 466.79 & 1076.04 & 258.94 \\
\hline 920 & 214.79 & 598.00 & 191.80 & 765.95 & 277.80 & 1008.89 & 448.63 & 1076.07 & 296.74 \\
\hline 940 & 211.98 & 589.07 & 189.28 & 761.44 & 272.68 & 979.33 & 438.46 & 1076.11 & 348.07 \\
\hline 960 & 209.21 & 580.19 & 186.82 & 756.98 & 267.79 & 950.76 & 428.71 & 569.31 & 410.70 \\
\hline 980 & 206.48 & 571.40 & 184.41 & 752.55 & 263.12 & 905.76 & 416.45 & 425.98 & 313.13 \\
\hline 1000 & 203.79 & 562.69 & 182.05 & 748.09 & 258.65 & 861.14 & 398.75 & 355.51 & 250.41 \\
\hline 1020 & 201.14 & 554.08 & 179.74 & 743.54 & 254.38 & 834.38 & 379.52 & 316.40 & 215.07 \\
\hline 1040 & 198.53 & 545.57 & 177.49 & 738.85 & 250.27 & 816.13 & 361.35 & 289.79 & 191.81 \\
\hline 1060 & 195.96 & 537.18 & 175.27 & 733.92 & 246.32 & 802.21 & 344.81 & 270.14 & 175.06 \\
\hline 1080 & 193.43 & 528.91 & 173.10 & 728.68 & 242.53 & 790.77 & 329.91 & 254.75 & 162.25 \\
\hline 1100 & 190.94 & 520.77 & 170.98 & 723.03 & 238.87 & 780.85 & 316.48 & 242.14 & 152.01 \\
\hline 1120 & 188.49 & 512.75 & 168.89 & 716.89 & 235.35 & 771.81 & 304.33 & 231.49 & 143.55 \\
\hline 1140 & 186.07 & 504.86 & 166.84 & 710.22 & 231.94 & 763.24 & 293.29 & 222.28 & 136.38 \\
\hline 1160 & 183.70 & 497.11 & 164.84 & 703.06 & 228.65 & 754.74 & 283.21 & 214.17 & 130.20 \\
\hline 1180 & 181.36 & 489.48 & 162.86 & 695.54 & 225.47 & 745.96 & 273.95 & 206.94 & 124.78 \\
\hline 1200 & 179.05 & 481.98 & 160.93 & 687.79 & 222.38 & 736.49 & 265.42 & 200.40 & 119.97 \\
\hline 1220 & 176.79 & 474.61 & 159.03 & 679.86 & 219.39 & 726.01 & 257.51 & 194.44 & 115.67 \\
\hline 1240 & 174.55 & 467.37 & 157.16 & 671.84 & 216.48 & 714.57 & 250.17 & 188.97 & 111.78 \\
\hline 1260 & 172.36 & 460.25 & 155.32 & 663.81 & 213.66 & 702.58 & 243.31 & 183.90 & 108.24 \\
\hline 1280 & 170.19 & 453.26 & 153.51 & 655.92 & 210.92 & 690.53 & 236.90 & 179.18 & 105.00 \\
\hline 1300 & 168.06 & 446.39 & 151.74 & 648.42 & 208.24 & 678.57 & 230.88 & 174.77 & 102.02 \\
\hline 1320 & 165.97 & 439.65 & 149.99 & 640.65 & 205.64 & 666.69 & 225.21 & 170.63 & 99.26 \\
\hline 1340 & 163.90 & 433.01 & 148.28 & 632.74 & 203.10 & 654.94 & 219.87 & 166.72 & 96.70 \\
\hline 1360 & 161.87 & 426.50 & 146.59 & 624.73 & 200.62 & 643.29 & 214.81 & 163.03 & 94.31 \\
\hline 1380 & 159.87 & 420.10 & 144.93 & 616.67 & 198.20 & 631.67 & 210.01 & 159.53 & 92.08 \\
\hline 1400 & 157.90 & 413.80 & 143.30 & 608.58 & 195.83 & 620.11 & 205.45 & 156.19 & 89.99 \\
\hline 1420 & 155.97 & 407.62 & 141.69 & 600.48 & 193.52 & 608.64 & 201.12 & 153.02 & 88.01 \\
\hline 1440 & 154.06 & 401.54 & 140.11 & 592.40 & 191.26 & 597.26 & 196.98 & 149.98 & 86.16 \\
\hline 1460 & 152.18 & 395.57 & 138.55 & 584.34 & 189.04 & 586.00 & 193.03 & 147.08 & 84.40 \\
\hline 1480 & 150.33 & 389.69 & 137.02 & 576.34 & 186.86 & 574.89 & 189.25 & 144.29 & 82.73 \\
\hline 1500 & 148.52 & 383.92 & 135.51 & 568.38 & 184.73 & 563.94 & 185.63 & 141.62 & 81.16 \\
\hline 1520 & 146.73 & 378.24 & 134.02 & 560.50 & 182.64 & 553.16 & 182.16 & 139.05 & 79.65 \\
\hline 1540 & 144.96 & 372.66 & 132.56 & 552.69 & 180.59 & 542.57 & 178.82 & 136.57 & 78.22 \\
\hline 1560 & 143.23 & 367.17 & 131.12 & 544.97 & 178.58 & 532.17 & 175.61 & 134.19 & 76.86 \\
\hline 1580 & 141.52 & 361.77 & 129.71 & 537.33 & 176.60 & 521.97 & 172.52 & 131.88 & 75.56 \\
\hline 1600 & 139.84 & 356.46 & 128.31 & 529.80 & 174.65 & 511.97 & 169.54 & 129.66 & 74.31 \\
\hline 1620 & 138.18 & 351.24 & 126.94 & 522.36 & 172.74 & 502.17 & 166.67 & 127.51 & 73.12 \\
\hline 1640 & 136.56 & 346.11 & 125.58 & 515.03 & 170.86 & 492.58 & 163.89 & 125.43 & 71.98 \\
\hline 1660 & 134.95 & 341.06 & 124.25 & 507.80 & 169.01 & 483.20 & 161.21 & 123.41 & 70.88 \\
\hline 1680 & 133.37 & 336.09 & 122.94 & 500.67 & 167.19 & 474.01 & 158.61 & 121.46 & 69.83 \\
\hline 1700 & 131.82 & 331.20 & 121.65 & 493.66 & 165.40 & 465.04 & 156.09 & 119.56 & 68.81 \\
\hline 1720 & 130.29 & 326.39 & 120.37 & 486.75 & 163.63 & 456.25 & 153.65 & 117.72 & 67.84 \\
\hline 1740 & 128.78 & 321.66 & 119.12 & 479.95 & 161.90 & 447.67 & 151.28 & 115.94 & 66.90 \\
\hline 1760 & 127.30 & 317.01 & 117.89 & 473.26 & 160.19 & 439.28 & 148.98 & 114.20 & 65.99 \\
\hline 1780 & 125.84 & 312.43 & 116.67 & 466.68 & 158.50 & 431.07 & 146.74 & 112.51 & 65.12 \\
\hline 1800 & 124.40 & 307.93 & 115.47 & 460.20 & 156.84 & 423.05 & 144.57 & 110.87 & 64.27 \\
\hline 1820 & 122.99 & 303.51 & 114.29 & 453.82 & 155.20 & 415.21 & 142.45 & 109.28 & 63.46 \\
\hline 1840 & 121.60 & 299.15 & 113.13 & 447.55 & 153.59 & 407.55 & 140.40 & 107.72 & 62.67 \\
\hline 1860 & 120.23 & 294.87 & 111.98 & 441.37 & 152.00 & 400.05 & 138.39 & 106.21 & 61.91 \\
\hline 1880 & 118.88 & 290.65 & 110.85 & 435.30 & 150.43 & 392.73 & 136.44 & 104.73 & 61.17 \\
\hline 1900 & 117.55 & 286.51 & 109.74 & 429.33 & 148.89 & 385.57 & 134.54 & 103.29 & 60.45 \\
\hline
\end{tabular}


COMSOL Multiphysics Model for DWPF Canister Filling SRNL-STI-2011-00209
Revision 1

September 8, 2011

\begin{tabular}{|c|c|c|c|c|c|c|c|c|c|}
\hline 1920 & 116.24 & 282.43 & 108.64 & 423.45 & 147.36 & 378.57 & 132.68 & 101.89 & 59.76 \\
\hline 1940 & 114.95 & 278.42 & 107.56 & 417.66 & 145.86 & 371.73 & 130.87 & 100.52 & 59.09 \\
\hline 1960 & 113.68 & 274.48 & 106.50 & 411.97 & 144.38 & 365.03 & 129.10 & 99.19 & 58.43 \\
\hline 1980 & 112.43 & 270.60 & 105.45 & 406.36 & 142.92 & 358.49 & 127.37 & 97.89 & 57.80 \\
\hline 2000 & 111.20 & 266.78 & 104.41 & 400.85 & 141.48 & 352.09 & 125.68 & 96.61 & 57.19 \\
\hline 2020 & 109.99 & 263.03 & 103.40 & 395.42 & 140.06 & 345.84 & 124.03 & 95.37 & 56.59 \\
\hline 2040 & 108.80 & 259.35 & 102.39 & 390.08 & 138.66 & 339.72 & 122.42 & 94.16 & 56.01 \\
\hline 2060 & 107.62 & 255.72 & 101.40 & 384.82 & 137.27 & 333.74 & 120.84 & 92.97 & 55.44 \\
\hline 2080 & 106.47 & 252.15 & 100.43 & 379.64 & 135.91 & 327.89 & 119.30 & 91.81 & 54.89 \\
\hline 2100 & 105.33 & 248.65 & 99.46 & 374.54 & 134.57 & 322.17 & 117.79 & 90.68 & 54.36 \\
\hline 2120 & 104.21 & 245.20 & 98.52 & 369.52 & 133.24 & 316.57 & 116.32 & 89.57 & 53.84 \\
\hline 2140 & 103.10 & 241.81 & 97.58 & 364.58 & 131.93 & 311.10 & 114.87 & 88.49 & 53.33 \\
\hline 2160 & 102.02 & 238.48 & 96.66 & 359.71 & 130.64 & 305.75 & 113.45 & 87.43 & 52.84 \\
\hline 2180 & 100.95 & 235.20 & 95.76 & 354.92 & 129.37 & 300.51 & 112.07 & 86.39 & 52.35 \\
\hline 2200 & 99.89 & 231.98 & 94.86 & 350.19 & 128.12 & 295.39 & 110.71 & 85.37 & 51.89 \\
\hline 2220 & 98.85 & 228.81 & 93.98 & 345.54 & 126.88 & 290.38 & 109.38 & 84.38 & 51.43 \\
\hline 2240 & 97.83 & 225.70 & 93.11 & 340.96 & 125.66 & 285.48 & 108.08 & 83.41 & 50.98 \\
\hline 2260 & 96.82 & 222.64 & 92.25 & 336.45 & 124.45 & 280.69 & 106.80 & 82.46 & 50.55 \\
\hline 2280 & 95.83 & 219.63 & 91.41 & 332.01 & 123.26 & 276.00 & 105.55 & 81.52 & 50.12 \\
\hline 2300 & 94.86 & 216.67 & 90.57 & 327.63 & 122.09 & 271.41 & 104.32 & 80.61 & 49.71 \\
\hline 2320 & 93.89 & 213.76 & 89.75 & 323.32 & 120.93 & 266.93 & 103.12 & 79.71 & 49.30 \\
\hline 2340 & 92.95 & 210.90 & 88.94 & 319.07 & 119.79 & 262.54 & 101.94 & 78.84 & 48.91 \\
\hline 2360 & 92.01 & 208.09 & 88.14 & 314.88 & 118.66 & 258.24 & 100.78 & 77.98 & 48.52 \\
\hline 2380 & 91.10 & 205.33 & 87.35 & 310.76 & 117.55 & 254.04 & 99.64 & 77.13 & 48.14 \\
\hline 2400 & 90.19 & 202.62 & 86.58 & 306.69 & 116.45 & 249.93 & 98.53 & 76.31 & 47.77 \\
\hline 2420 & 89.30 & 199.95 & 85.81 & 302.69 & 115.37 & 245.91 & 97.43 & 75.50 & 47.41 \\
\hline 2440 & 88.42 & 197.32 & 85.06 & 298.75 & 114.30 & 241.97 & 96.36 & 74.71 & 47.06 \\
\hline 2460 & 87.56 & 194.74 & 84.31 & 294.86 & 113.25 & 238.12 & 95.31 & 73.93 & 46.72 \\
\hline 2480 & 86.70 & 192.20 & 83.58 & 291.04 & 112.21 & 234.35 & 94.27 & 73.16 & 46.38 \\
\hline 2500 & 85.87 & 189.71 & 82.85 & 287.26 & 111.19 & 230.66 & 93.26 & 72.42 & 46.05 \\
\hline 2520 & 85.04 & 187.26 & 82.14 & 283.55 & 110.17 & 227.05 & 92.26 & 71.68 & 45.73 \\
\hline 2540 & 84.22 & 184.85 & 81.43 & 279.89 & 109.17 & 223.52 & 91.28 & 70.96 & 45.41 \\
\hline 2560 & 83.42 & 182.48 & 80.74 & 276.29 & 108.19 & 220.06 & 90.32 & 70.25 & 45.10 \\
\hline 2580 & 82.63 & 180.15 & 80.05 & 272.73 & 107.21 & 216.67 & 89.38 & 69.56 & 44.80 \\
\hline 2600 & 81.85 & 177.85 & 79.38 & 269.24 & 106.25 & 213.36 & 88.45 & 68.88 & 44.50 \\
\hline 2620 & 81.09 & 175.60 & 78.71 & 265.79 & 105.30 & 210.11 & 87.54 & 68.21 & 44.21 \\
\hline 2640 & 80.33 & 173.38 & 78.05 & 262.40 & 104.37 & 206.93 & 86.64 & 67.56 & 43.93 \\
\hline 2660 & 79.59 & 171.20 & 77.41 & 259.05 & 103.45 & 203.82 & 85.76 & 66.91 & 43.65 \\
\hline 2680 & 78.86 & 169.06 & 76.77 & 255.76 & 102.53 & 200.77 & 84.90 & 66.28 & 43.37 \\
\hline 2700 & 78.13 & 166.95 & 76.14 & 252.52 & 101.63 & 197.78 & 84.05 & 65.66 & 43.11 \\
\hline 2720 & 77.42 & 164.88 & 75.51 & 249.32 & 100.75 & 194.85 & 83.22 & 65.05 & 42.84 \\
\hline 2740 & 76.72 & 162.84 & 74.90 & 246.17 & 99.87 & 191.99 & 82.40 & 64.46 & 42.59 \\
\hline 2760 & 76.03 & 160.83 & 74.29 & 243.08 & 99.00 & 189.18 & 81.59 & 63.87 & 42.34 \\
\hline 2780 & 75.35 & 158.86 & 73.70 & 240.02 & 98.15 & 186.43 & 80.80 & 63.29 & 42.09 \\
\hline 2800 & 74.68 & 156.92 & 73.11 & 237.02 & 97.30 & 183.73 & 80.02 & 62.73 & 41.85 \\
\hline 2820 & 74.02 & 155.01 & 72.53 & 234.06 & 96.47 & 181.09 & 79.25 & 62.17 & 41.61 \\
\hline 2840 & 73.37 & 153.14 & 71.95 & 231.14 & 95.65 & 178.50 & 78.50 & 61.62 & 41.37 \\
\hline 2860 & 72.73 & 151.29 & 71.39 & 228.27 & 94.84 & 175.96 & 77.76 & 61.09 & 41.15 \\
\hline 2880 & 72.10 & 149.47 & 70.83 & 225.44 & 94.03 & 173.47 & 77.03 & 60.56 & 40.92 \\
\hline 2900 & 71.48 & 147.69 & 70.28 & 222.66 & 93.24 & 171.03 & 76.31 & 60.04 & 40.70 \\
\hline 2920 & 70.86 & 145.93 & 69.73 & 219.92 & 92.46 & 168.63 & 75.61 & 59.53 & 40.49 \\
\hline
\end{tabular}


COMSOL Multiphysics Model for DWPF Canister Filling SRNL-STI-2011-00209
Revision 1

September 8, 2011

\begin{tabular}{|l|l|l|l|l|l|l|l|l|l|}
\hline 2940 & 70.26 & 144.20 & 69.20 & 217.22 & 91.69 & 166.29 & 74.92 & 59.03 & 40.27 \\
\hline 2960 & 69.66 & 142.50 & 68.67 & 214.56 & 90.93 & 163.99 & 74.23 & 58.54 & 40.07 \\
\hline 2980 & 69.08 & 140.82 & 68.15 & 211.94 & 90.17 & 161.73 & 73.56 & 58.06 & 39.86 \\
\hline 3000 & 68.50 & 139.18 & 67.63 & 209.36 & 89.43 & 159.52 & 72.90 & 57.58 & 39.66 \\
\hline
\end{tabular}




\section{Distribution}

J. W. Amoroso, 999-W

A. B. Barnes, 999-W

C. L. Crawford, 773-42A

D. A. Crowley, 773-43A

A. P. Fellinger, 773-41A

S. D. Fink, 773-A

K. M. Fox, 999-W

B. J. Giddings, 786-5A

N.K. Gupta, 703-41A

C. C. Herman, 999-W

C. M. Jantzen, 773-A

F. C. Johnson, 999-W

M.R. Kesterson, 703-41A

P.L. Lee, 703-41A

S. L. Marra, 773-A

D. K. Peeler, 999-W

F. M. Pennebaker, 773-42A

M. E. Stone, 999-W

D.A. Tamburello, 703-41A

W. R. Wilmarth, 773-A 